\title{
Tattooed and Non-Tattooed Women: Motivation, Social Practices and Risk Behavior
}

\author{
Adriano Schlösser ${ }^{1}$ \\ Andréia Isabel Giacomozzi $i^{2}$ \\ Brigido Vizen Camargo ${ }^{2}$ \\ Emanuely Zelir Pereira da Silva ${ }^{2}$ \\ Marlon Xavier ${ }^{3}$ \\ ${ }^{1}$ Universidade do Oeste de Santca Catarina \\ ${ }^{2}$ Universidade Federal de Santa Catarina \\ ${ }^{3}$ Universitat Oberta de Catalunya
}

\begin{abstract}
This study aimed at identifying motivations, risk behavior and social practices, comparing tattooed and non-tattooed women. 316 women $(50 \%$ tattooed) were surveyed online, answering questions on sociodemographic data, social practices, motivations, and risk behavior. Data collection strategies included snow-balling, social networks, personal contact, and visits to tattoo parlors. The main results indicate that the majority of women express satisfaction with their physical appearance after getting tattooed, and wouldn't get the tattoo removed. Being tattooed correlated with risk behaviors such as casual sex with unknown people, alcohol and drug use, and psychopathology. The sample presented more similarities than differences between tattooed and non-tattooed groups, suggesting that growing popularization and social acceptance of tattooing has led to a decrease of the differences between the groups. Such results may inform future research and the production of informative materials aimed at demystifying negative stereotypes associated to tattoos.
\end{abstract}

Keywords: body; social psychology; body marking.

\section{Mulheres Tatuadas e Não Tatuadas: Motivações, Práticas Sociais e Comportamento de Risco}

\section{Resumo}

O objetivo foi identificar as motivações, práticas sociais e comportamento de risco de mulheres tatuadas e não tatuadas. Participaram 316, divididas igualmente entre as categorias. As estratégias de acesso aos participantes foram variadas: técnica de snowball, redes sociais, contato pessoal e idas a estúdios de tatuagem. A coleta de dados ocorreu por meio de um survey on-line, composto por: questões sociodemográficas, práticas sociais, motivações e comportamento de risco. Os principais resultados indicam que a maioria das mulheres apresenta satisfação com sua aparência após realizarem tatuagem e não as removeriam. Houve associação entre ter tatuagem e comportamento sexual de risco, prática sexual com desconhecidos, álcool e outras drogas e psicopatologia. A amostra apresentou mais semelhanças do que diferenças, sugerindo que a popularização e aceitação social da tatuagem têm refletido na diminuição das diferenças entre tatuados e não tatuados. Tais resultados podem permitir a construção de informativos que contribuam na desmistificação de estereótipos negativos frente à tatuagem.

Palavras-chave: corpo, psicologia social, marcas corporais

\section{Mujeres con Tatuajes y sin Tatuajes: Motivaciones, Prácticas Sociales y Comportamiento de Riesgo}

\section{Resumen}

El objetivo de este estudio fue identificar motivaciones, comportamiento de riesgo y prácticas sociales, entre mujeres con tatuajes y sin tatuajes. Participaron 316 mujeres 50\% tatuadas y $50 \%$ no tatuadas. Las estrategias de acceso a los participantes fueron variadas: técnica de snowball-bola de nieve), redes sociales, contacto personal e idas a estudios de tatuaje. La recolección de datos ocurrió a través de un levantamiento online compuesto por preguntas sobre datos sociodemográficos, prácticas sociales, motivaciones y comportamiento de riesgo. Los principales resultados indican que la mayoría de las mujeres expresan satisfacción con su apariencia física después de tatuarse y no se quitarían el tatuaje. Hubo asociación entre tener tatuaje y comportamiento sexual de riesgo, práctica sexual con desconocidos, alcohol y otras drogas y psicopatología. La muestra presenta más semejanzas que diferencias entre los dos grupos, sugiriendo que la popularidad y aceptación social del tatuaje han llevado a la disminución de las diferencias entre los dos grupos. Los resultados pueden permitir la construcción de materiales informativos que contribuyan para la desmitificación de estereotipos negativos frente al tatuaje.

Palabras clave: cuerpo; psicología social; marcas corporales

\section{Introduction}

Today, tattooing is considered one of most prevalent practices of body modification worldwide
(Atkinson, 2002). Yet, until recently, tattoos were associated with social outsider or deviant groups such as prison inmates, sailors, gang members, prostitutes, hippies, punks and other groups seen as socially marginal, 
and labeled as a marker of transgression and deviant behavior. However, recent studies have pointed to alterations in such social stereotype. Tattooed individuals were perceived to be as suitable for employment as non-tattooed ones, suggesting the emergence of a new stereotype for the new generations (Burgess \& Clark, 2010; Tate \& Shelton, 2008).

As regards tattooed women, as a group it has endured intense social stigmatization for transgressing both social and gender norms - the "gendered body" (Atkinson, 2002). In a study on career-oriented women with tattoos (Armstrong, 1991), 70\% of them reported having engaged in risk-seeking behavior. Degelman and Price (2002) found that tattooed women were rated as less attractive, honest, generous and intelligent than non-tattooed women. In a study on body modification, self-esteem, and body investment in adolescent girls, Carroll and Anderson (2002) reported that body modifications were significantly correlated with trait anger-reaction. Hawkes, Senn and Thorn (2004) indicated that attitudes regarding women with visible tattoos were more negative in both sexes, the size of the tattoo being a predictor of evaluation only for non-tattooed men and women. In a study by Seiter and Hatch (2005), tattooed women were rated as less credible but not less attractive. Swami and Furnham (2007) found that tattooed women were considered less attractive, more sexually promiscuous and more prone to engaging in risk behavior, such as alcohol abuse. Wiseman (2010) assessed undergraduates' perceptions of tattoos on a female college instructor; the presence of tattoos was associated with positive ratings in students' motivation and how likely they were to recommend her as an instructor.

As regards health, Thompson (2015) found that tattooed women were just as psycho-socially healthy as non-tattooed women. Kluger (2015) did not identify pregnancy problems in tattooed women (tattooists), contradicting the idea that tattoos could cause fetus malformation.

Studies comparing female and male populations have also brought about relevant data, such as the research by Drews, Allison and Probst (2000), who found that tattooed women were more likely to report use of drugs other than alcohol, shoplifting, and body piercings. Wohlrab, Fink, Kappeler, and Brewer (2009) found that, whereas images of tattooed male characters were rated as more dominant, tattooed female characters were perceived as less healthy compared with their non-tattooed counterparts. Perhaps traditional gender stereotypes - women seen as more fragile and less capable of enduring risks associated with tattooing - play a role in such results

As regards sexual behavior, Koch, Roberts, Armstrong and Owen (2005) cite that no significant difference was found between tattooed and non-tattooed college women in relation to the age at which they become sexually active. However, Guéguen (2012) reported earlier experiences of sexual intercourse in tattooed students of both sexes. Research have also found that female students are more likely to get involved in body modification practices (King \&Vidourek, 2013).

In comparison with the international literature, there is a dearth of empirical psychological research in the Brazilian context (or with the Brazilian population).Most Brazilian studies are theoretical and employ a qualitative approach (Bicca, Duquia, Breunig, Souza, \& Almeida, 2013; Corso \& Corso, 2014; Dadalte, Mariano, Pedrão, \& Soares, 2013; Macedo \& Paravidini, 2014; Macedo, Paravidini, \& Próchno, 2014; Pinheiro \& Carvalho, 2017; Rodriguez \& Carreteiro, 2014), viewing tattoos mostly as a form of subjectivation, as a search for identity through symbolic means. Studies with quantitative and psychometric approaches are thus lacking in the Brazilian context (Conti et al., 2012; Gouveia, et al., 2010; Medeiros, Gouveia, Pimentel, Soares, \& Lima, 2010)

Drawing from the recent literature reviewed, this study puts forward as a main hypothesis that tattooed and non-tattooed women will not present differences as regards risk behaviors, taking into account the aesthetic character connected to tattooing today.

Considering the relevance of tattooing practices today, more studies on the theme are needed in the Brazilian context. From a psycho-social viewpoint, the transformation of values, beliefs, and meanings connected to tattooing practices is noticeable indeed. Such transformations are also connected to contemporary ways of conceiving the body as an individual and social construction. Drawing from such observations, this study aimed at identifying the motivations for getting tattooed and its relations with risk behavior and other social practices, comparing such factors in tattooed and non-tattooed Brazilian women.

\section{Method}

\section{Participants}

This study has a descriptive-comparative, transversal nature, employing purposive sampling. A 
convenience sample of 316 women (50\% tattooed), over 18 years of age, were surveyed online between May and September 2017; completion of the survey took approximately 10 minutes.

\section{Instrument}

A self-reported online questionnaire was developed for this study, with both open-ended and closed-ended items, based on previous instruments found in previous researches (Deschesnes, Finès, \& Demers, 2006; Dickson, Dukes, Smith, \& Strapko, 2014; Martin \& Dula, 2010). The questionnaire was composed by 16 questions, divided in 4 sections, addressing the following topics: a) sociodemographic data (5 questions): age, marital status, religious beliefs, level of education, and number of tattoos; b) descriptive questions about social practices (4 questions): having tattoo(s) either acquired in tattoo parlors or elsewhere, visibility of tattoo, attractiveness, and prejudice; c) descriptive questions about motivations for acquiring or not a tattoo (2 questions); and d) descriptive questions about risk behaviors and psychological conditions (5 questions): sexual behavior, use of alcohol/other drugs, presence of psychopathology and suicidal ideation.

\section{Data collection}

The research project obtained assent from UFSC's Research with Humans Ethics Committee, protocol n. 1.353.995, and all its ethical guidelines were respected, following norms contained in Resolution n. 510/2016, Brazilian National Council of Health, on research in the Social and Human Sciences that involves human beings. Before research began, participants were asked to read and sign an Informed Consent form presented in the first section of the questionnaire.

A preliminary contact was made - through e-mail, social networks, and personal contact - to reach tattooed and non-tattooed individuals, who had to be over 18 years of age. Researchers also contacted tattoo studios and used a (virtual) snowball technique, in that participants referred the questionnaire to their acquaintances.

A pilot study using the instrument was carried on with 20 participants, and also online, aiming at assessing whether the questionnaire fulfilled the research objectives, and at improving it so as to build a definitive version. The pilot study results confirmed that the questions did not need modifications, so the questionnaire remained as it was in its definitive version. Prior to questionnaire presentation, the participants had access to general information on the research and a guarantee on the confidentiality of their data; they were told they could quit answering when they wished to do so.

\section{Data analysis}

Descriptive statistical analysis (mean, standard deviation, frequency distribution) and relational analysis (Chi-square test for the relationships on nominal variables) were employed. Data were entered into a spreadsheet and analyzed with the Statistical Package for Social Sciences (SPSS-17.0) software. The answers to the open-ended questions were tabulated and analyzed via simple frequency through Microsoft Excel software.

\section{Results}

\section{Sample characteristics}

Participants included 316 women $(50 \%$ of them tattooed). Meanage of tattooed women is 31.4 years ( $S D=12.3$ years) and of non-tattooed women is 29.17 years ( $S D=8.23$ years). Most $(37.5 \%)$ reported being either married or in a stable relationship, while $30.3 \%$ were single and $26.5 \%$ dating; $5.4 \%$ reported being divorced and $0.3 \%$ widowed. There was no significant statistical association between marital status and possessing or not a tattoo.

Regarding the participants' level of education, $38.8 \%$ had incomplete university education, followed by post-graduation level $(32.8 \%)$, complete university education (23.4\%), complete high school (3.2\%), incomplete high school (1.6\%) and complete elementary school $(0.3 \%)$. There was no significant statistical association between having a tattoo and level of education.

Concerning the participants' religious beliefs, most $(31.9 \%)$ declared to be Catholic, while $24.6 \%$ believe in a superior force but do not follow a specific religion, $13.2 \%$ are atheists, $11.4 \%$ follow Spiritism, $8.2 \%$ were agnostics, $6.3 \%$ Evangelicals, $1.6 \%$ Buddhists and $2.8 \%$ have other beliefs. It is noteworthy that the majority of participants who said they were atheists were tattooed (57.1\%), and the same happened with the ones who believe in a superior force $(59 \%)$. However, among the self-reported Catholics such relationship is inverted, with the majority being non-tattooed (60.6\%) - which also occurs among Evangelicals, $70 \%$ of whom declared not having tattoos. Spiritism was the only form of instituted religion whose adherents were mostly tattooed women $(61.1 \%)$. There was a significant statistical association between having a tattoo and religious beliefs $\left[\chi^{2}=15.93 ; \mathrm{gl}=7\right.$; $\left.\mathrm{p}<.05\right]$. 


\section{Social practices}

Regarding tattooing practices, $78.6 \%$ of the tattooed participants reported they acquired their tattoo(s) in tattoo parlors. However, $14.5 \%$ said that they had gotten a tattoo elsewhere, and $6.9 \%$ got tattooed elsewhere more than once.

Concerning the participants' tattoo visibility, $37,5 \%$ said their tattoos were visible when wearing shorts, camisole, or open shoes; $25 \%$ affirmed they are visible if they wear shirts, t-shirts, and trousers, while $19,4 \%$ said their tattoos are always visible, 12,5\% reported their tattoos were visible only when they wear only underwear or bathing suits, and only 5,6\% said their tattoos are rarely visible. Most participants (43.7\%) reported they had a tattoo and wanted to acquire more, $18.3 \%$ were non-tattooed but planned to get tattooed, $18.3 \%$ didn't have tattoos and don't want to, $12 \%$ didn't have tattoos but wanted to, $5.7 \%$ were tattooed and satisfied with the tattoo(s) they already had. Only $2 \%$ said they were tattooed but regretted it.

As regards prejudice, $14.6 \%$ of the tattooed participants reported having suffered it on account of their tattoos. Besides, $25.8 \%$ of them said some family member had a negative reaction when the tattoo was acquired, while $37.2 \%$ said family members maintained their negative attitude long after they got tattoos. However, the family home was the most cited context for discrimination and/or prejudice, with 10 mentions, followed by workplace (7), and public and religious spaces, both with 2 mentions each.

Among the reasons given for the family member(s) being against the tattoo were: fear that their sibling(s) suffered social prejudice or prejudice by family members caused by stereotypes of tattooed persons (22 mentions); one or more members don't like tattoos (18 mentions); religious beliefs, "unnecessary/ugly" and concerns regarding employability (7); fear of regret (4); tattoo size (3); and conservativeness, with 1 mention.

Asked whether they believed they had become more attractive after acquiring their tattoo(s), 48.4\% of tattooed participants answered yes and 51.6\% no. Among the main reasons cited by participants for the attractiveness of tattooed individuals were personality (30 mentions), followed by personal style and/or body location (27), sexy/attractive/sensual/pretty (23), proof of courage/force/attitude (20), statement of identity (15), curiousness regarding the tattoo's meaning (10), personal taste (8). Only 32 participants said they were indifferent to tattoos as concerns attractiveness.

\section{Motivations for getting tattooed}

The largest proportion $(30.9 \%)$ of participants cited their tattoos as a form of personal expression, followed by a means to remember a significant person $(26.8 \%)$ and expression of identity (24.9\%). For $24.3 \%$ of the tattooed participants, the tattoo represents a mark through which they remember a life experience or story; for $18.3 \%$ it is regarded as an artistic expression, or else an aesthetic one (11.4\%), and has as a main effect to augment physical attractiveness $(9.8 \%)$ or show femininity (7.6\%), but also force and resistance (7.3\%); only few (5\%) participants said that they got their tattoo(s) on impulse. Fewer than $5 \%$ of participants mentioned the following motivations: as a tool for protection or religious expression, to remember a traumatic experience, as a form of altering a body mark or scar, dissatisfaction with physical appearance, as a form of transgression or rebellion, as a badge of belonging to a group, fashion, and pain. The vast majority $(98.1 \%)$ of the tattooed participants reported being satisfied with their appearance after getting their tattoo(s), and $76.7 \%$ said they wouldn't remove them. Among the ones who would remove them, $8.8 \%$ would get one or more tattoos because they thought the one they had was ugly, and 5\% would remove it because it had lost its meaning.

Regarding motivations for not having a tattoo, the non-tattooed participants mentioned most fear of pain $(22.7 \%)$, followed by concern over the tattoo appearance in old age $(19.6 \%)$, high financial cost $(15.5 \%)$, concern with social norms, such as lack of family approval $(9.8 \%)$, reckoning that the tattoo wouldn't be pretty on them $(9.5 \%)$, negative repercussion at the workplace $(8.2 \%)$, health risk $(7.3 \%)$, and religious considerations $(4.1 \%)$. Other motives that were less cited were: social evaluation, tattoo as vulgar, regret, concern or indecision over the artwork's beauty, as well as lack of desire to get tattooed and concerns over long-term ink lasting on skin.

\section{Risk behaviors}

As regards the participants' sexual life, the majority of both non-tattooed (87.9\%) and tattooed (82.3\%) participants reported having had two or less sexual partners in the previous year, whereas $10.2 \%$ of the non-tattooed ones and $13.3 \%$ of the tattooed ones cited 3 to 5 sexual partners in the same period; the same percentage $(1.9 \%)$ in both groups had had between 6 and 10 sexual partners. There was no significant statistical association between the variables $\left[\chi^{2}=4.91 ; \mathrm{gl}=3\right.$; $\mathrm{p}$ 
$=$ NS]. Table 1 shows the percentages of variables associated with risk behaviors with significant association.

A larger proportion of tattooed participants reported having casual sexual with unknown or semiknown partners occasionally $(36.7 \%)$ in comparison with $22.9 \%$ of the non-tattooed participants; there was a significant statistical association between the variables $\left[\chi^{2}=7.19 ; \mathrm{gl}=2 ; \mathrm{p}<.05\right]$. The majority of non-tattooed women $(75.2 \%)$ affirmed they had never had casual sex with strangers, against $62 \%$ of the tattooed women.

As regards condom use, there was no significant statistical association between having a tattoo and using condoms $\left[\chi^{2}=1.7 ; \mathrm{gl}=2 ; \mathrm{p}=\mathrm{NS}\right]$. However, more tattooed participants $(41.1 \%)$ reported that they occasionally had sex without using a condom, while only $35 \%$ of the non-tattooed participants said the same. On the other hand, a higher proportion of non-tattooed women $(40.1 \%)$ reported they never engaged in unprotected sex, in comparison with $35.5 \%$ of the tattooed women. A similar percentage of both groups $(25.3 \%$ of the tattooed and $24.8 \%$ of non-tattooed) informed they always have unprotected sex.

The variable condom use varied in accordance with the marital status declared by the participants. Among the ones who mentioned they were married or in a stable relationship or dating $(34.2 \%)$, the percentage of participants who affirmed always having unprotected sex was large $(64.2 \%$ for the married ones and $34.2 \%$ for the ones with a boyfriend), whereas many self-declared single participants $(44.8 \%)$ never engage in unprotected sex. There was a significant statistical association between the variables marital status and condom use $\left[\chi^{2}=45.35 ; \mathrm{gl}=8 ; \mathrm{p}=.000\right]$.

Regarding alcohol consumption, $61.2 \%$ of the participants reported occasional use. Crossing having tattoos with alcohol use, it is noticeable that, among the women who were teetotalers, $70.3 \%$ were non-tattooed, while among the ones who reported drinking socially every week, $56.7 \%$ were tattooed. As regards occasional use of alcohol, the same proportion (50\%) was seen in both groups. There was a significant statistical association between the variables $[\chi 2=9.86 ; \mathrm{gl}=3 ; \mathrm{p}<.05]$.

Regarding tobacco use, $68.8 \%$ of the participants said they never had used it, $25.9 \%$ use occasionally and $5.4 \%$ smoke every day. Among the first group, most were non-tattooed (56.4\%), while $43.6 \%$ were tattooed; among the second group, most were tattooed (60.5\%). As regards the last group, of daily smokers, $87.5 \%$ are tattooed, with a significant statistical association $\left[\chi^{2}=\right.$ 16.16; $\mathrm{gl}=2 ; \mathrm{p}=.000]$.

Regarding marijuana or hashish use, $79.5 \%$ of the participants said they never used them, $17.7 \%$ cited occasional use and $2.8 \%$ constant use. There was a significant statistical association between having tattoos and marijuana use $[\chi 2=9.30 ; \mathrm{gl}=2 ; \mathrm{p}<.05]$; it is noteworthy that, among the participants who didn't use the substance, $53.6 \%$ were non-tattooed and $46.4 \%$ were tattooed, whereas among the ones who mentioned occasional use, $60.7 \%$ were tattooed and $39.3 \%$ nontattooed. As for the group who reported constant use, $88.9 \%$ had tattoos and $11.1 \%$ didn't have.

Questioned about the use of other illicit drugs, $90.9 \%$ reported not using them, $8.8 \%$ cited occasional use and $2.8 \%$ frequent use. Among the first group, $52.1 \%$ are non-tattooed and $47.9 \%$ are tattooed, while among the ones who occasionally use $71.4 \%$ have tattoos and $28.6 \%$ don't. There was a significant statistical association between the variables $\left[\chi^{2}=6.65 ; \mathrm{gl}=2 ; \mathrm{p}<.05\right]$.

As regards mental health, $15.8 \%$ of the sample mentioned having some form of psychiatric diagnosis. Among the psychiatric disorders cited by tattooed participants, 27 mentioned depressive disorder, followed

Table 1.

Risk behaviors with significant association of participants

\begin{tabular}{lcc}
\hline Risk behaviors & Tatooed & Non Tattooed \\
\hline & & $22.9 \%$ \\
Casual sex with unknown or semi-known & $36,7 \% *$ & $12.5 \%$ \\
Tobacco daily smokers & $87,5 \% \%^{* * *}$ & $39.3 \%$ \\
Marijuana or hashish ocasional use & $60,7 \% *$ & $47.9 \%$ \\
Illicit drugs occasional use & $52,1 \% *$ & \\
\hline
\end{tabular}

*p .05; *** p.005. 
by anxiety disorder (13 mentions), panic disorder (8), bipolar and personality (borderline and unspecified) disorders, both with 3 mentions each, attention deficit hyperactivity disorder and posttraumatic stress disorder (1 mention each). Crossing the variable being tattooed with psychiatric diagnosis, it was observed that, among the participants who reported having a psychiatric diagnosis, $68 \%$ were tattooed and $32 \%$ were not; whereas $53.2 \%$ of the participants who reported not having a psychiatric diagnosis were non-tattooed. There was a significant statistical association between the variables $\left[\chi^{2}=7.56 ; \mathrm{gl}=12 ; \mathrm{p}<.05\right]$.

Regarding suicidal ideation, both groups (tattooed and non-tattooed women) gave very similar answers, so there was no significant statistical association between the variables being tattooed and suicidal ideation $\left[\chi^{2}\right.$ $=.025 ; \mathrm{gl}=1$; NS], for $33.1 \%$ of non-tattooed participants and $32.3 \%$ of the tattooed ones mentioned having contemplated suicide.

\section{Discussion}

This study examined the motivations for getting tattooed and its relations with risk behaviors and other social practices, comparing a sample of tattooed and non-tattooed Brazilian women. Our dataset shows an association between being tattooed and a higher rate of health risk behaviors, such as promiscuous sexual behaviors and tobacco, alcohol, marijuana, and other substance use. Such results replicate findings from other (international) studies, which correlate tattooing and risk behaviors such as greater use of tobacco, alcohol and other drugs, violence, and lower mental health. These findings were corroborated in samplings of tattooed individuals across different countries, such as Argentina (Busaniche, Eymann, Mulli, Paz, \& Catsicaris, 2006), Australia (Heywood et al., 2012), England (Jennings, Fox, \&Farrington, 2014), France (Gueguén, 2012), Ukraine (Sosin, 2014), and the USA (Forbes, 2001; King \&Vidourek, 2013), amongothers.

Regarding sexual behavior, in this study's sample there was no strong association between being tattooed and risk practices, contradicting research that associates tattooed people to a higher propensity to risk sexual behaviors, such as, e.g., greater number of sexual partners and engaging in unprotected sex (Heywood et al., 2012; King \&Vidourek, 2013; Koch, Roberts, Armstrong, \& Owen, 2010; Swami \& Furnham, 2007). Although our data point to a significant association between being tattooed and engaging in sexual practices with unknown or semi-known people, caution is warranted due to the sample size and values that are close to the ones found with non-tattooed women. Personality traits such as openness to new experiences and sensation- and adventure-seeking proneness may be seen as a hypothetical cause for both sexual risk behaviors and being tattooed, and appear in different studies on tattooed people (Drews et al., 2000; Stirn et al., 2006; Swami, 2012; Swami et al., 2012; Tate \& Shelton, 2008; Tiggeman \& Golder, 2006; Wohlrab et al., 2009).

This study did not find association between being tattooed and suicidal ideation, although other studies suggest there is a connection between being tattooed and suicide risk in adults (Solano et al.2014; Yen et al., 2012), that connection being stronger in tattooed women (Carrol \&Anderson, 2002). Our results agree with the recent results published by King and Vidourek (2013), which didn't correlate suicidal behavior with tattooing practices.

As regards motivations for getting tattooed, findings for the Brazilian population point to three main motives: as an avenue of self-expression, of identity/ singularity, and as memento of a significant person, which were also found in diverse studies (Atik \& Yildirim, 2014; Atkinson, 2002; Byard \& Charlwood, 2014; Chakraborty, 2013; Dadalte et al., 2013; Le Breton, 2016; Owen, Armstrong, Koch, \& Roberts, 2013; Tiggemann \&Hopkins, 2011; Wohlrab, Stahl, \& Kappeler, 2007).The same holds for motivations related to attractiveness, art form, and fashion (Czupy, Pongó, Mihálffy, \& Susánzky, 2016; Kierstein \& Kjelskau, 2015; Koziel \& Sitek, 2013; Kosut, 2014; Pajor, Broniarczyk-Dyła, \&Świtalska, 2015; Thakur \& Verma, 2016). Getting tattooed on impulse was also seen as motivation in our sample, but in low rates. Though the literature (Stirn, Hinz, \& Brähler, 2006; Stirn, Brähler, \& Hinz, 2006) underlines the importance of impulsive decision making, we agree with Forbes (2001), who found that tattoo practices tend to be carefully planned, especially in adults.

The motivations of non-tattooed people for not getting a tattoo found in this study also concur with the ones mentioned in other studies. Studies on the social perception of tattooed individuals report that it tends to be negative, associated to risk behaviors (Forbes, 2001), or else associating non-tattooed individuals to more valued characteristics such as intelligence, religious, or honesty, for instance (Degelman \& Price, 2002; Seiter $\&$ Hatch, 2005). The findings in this study did not identify, as regards motivation, answers associated to risk 
behavior; they were mostly connected to perception of context, confirming findings from previous studies that connected being tattooed to a less conservative appearance and less credibility (Seiter \& Sandry, 2003), also influencing impression formation in the context of professional recruitment of women with visible tattoos (Aktinson, 2002).

As regards tattooing and health practices, in our sample the majority of tattooed participants got tattooed in tattoo studios. In addition to the professional procedures related to health (disinfection, sterilization of materials etc.) offered by studios, technical advance has also contributed to their popularization, such as development of safer pigments, more sophisticated equipment, and new asepsis procedures. Professionalization of tattooists has also proved important for the growing social acceptance of tattooing practices (Swami \& Furnham, 2007).

Regarding tattoo size, the majority of our tattooed participants had semi-visible tattoos, which can be hidden in case of necessity. In a study comparing samples of tattooed and non-tattooed people, Adams (2009) found that highly visible placement of tattoos was strongly associated with deviant behaviors. One of the principal settings in which such association occurs is the workplace, for tattooed individuals tend to be perceived in a more negative fashion and seen as less professional or less capable of doing their jobs (Aktinson 2002; Armstrong, Roberts, Koch, Sauders, Owen, \& Anderson, 2008; Stuppy et al., 1998),although other studies found that individuals with contemporary tattoos were perceived in the same way as non-tattooed ones as regards professional capacity, which suggests that the new generations are changing their stereotypes (Burgess \& Clark, 2010; Tate \& Shelton, 2008).

In relation to the religious factor, it is well known that religiosity tends to be a strong influence on beliefs and practices, for religious people tend to identify with the norms and values of their religious groups (Koch, Roberts, Armstrong, \& Owen, 2004). Prior studies have associated tattooing practices with religiosity (Kluger, 2012; Koch \& Roberts, 2012). Koch et al., (2004) found a weak and negative correlation between religion and tattooing, suggesting a higher cultural acceptance of tattooing practices. Rivardo and Kelan (2010) did not find significant correlations between body modification practices and religious variables either.

However, the specific Brazilian religious context, characterized by an upsurge in the number of Pentecostal and Neo-Pentecostal churches that consider body modification practices as sinful and forbidden, may have a very different impact in the association of such variables, in comparison with other countries - which calls for more studies in depth. Considering such context, we may hypothesize that atheist or non-religious women might be more likely to get tattooed. Absence of religious affiliation was associated with tattooing practices in the studies of Laumann and Derick (2006) and Stirn, Hinz and Brähler (2006). In our study, the majority of self-reported followers of Spiritism were tattooed; that can perhaps be ascribed to the fact that Spiritism does not condemn tattooing.

Regarding prejudice, in our sample a significant number of tattooed women reported suffering prejudice or discrimination in different contexts. Although it has been argued that the growing association of tattooing with artistic and aesthetic expression has distanced tattooing from its old negative associations (Burgess \& Clark, 2010; Forbes, 2001; Tate \& Shelton, 2008), increasing its social acceptance and popularity, it still activates longstanding stereotypes, especially among older generations, which tend to associate tattoos with deviance, criminality, and the working class (Adams, 2009). Several studies confirm the existence of prejudicial and discriminatory attitudes towards tattooed women (Degelman \& Price, 2002; Hawkes et al., 2004; Seiter \& Hatch, 2005; Swami \& Furnham, 2007), warranting cautiousness in the analysis of such practices. As regards prejudice and relationships with family members, the percentage of individuals who didn't modify their (negative) opinion about tattooing even when they were close to a tattooed acquaintance/family member underlines the resistance of nuclear beliefs and values. Yet studies have shown that having tattooed friends and family members diminishes stigma and heightens acceptation (Dickson et al., 2014), with friends influencing twice as much in that regard in comparison with family members (Roberts, Koch, Armstrong, \& Owen, 2006).

Concerning attractiveness, we found that the percentage of tattooed women who reported feeling more attractive and of the ones who didn't is virtually identical. Three hypotheses were put forward: a) to feel more attractive for being tattooed may be contra-normative, i.e., although there might be a more positive attitude regarding oneself aesthetically, such attitude cannot be verbalized, which can diminish the social value of tattooing; b) the motive for getting tattooed was not originally aesthetic, which does not lead one to think of oneself as more attractive for being tattooed; c) to 
feel more attractive might have been interpreted as "to others" - i.e. more in an interpersonal rather than in an intrapersonal sense. However, a number of studies support the idea that many individuals get tattooed in order to become more attractive (Drews et al., 2000; Koziel \& Sitek, 2013; Seiter \& Hatch, 2005; Wohlrab et al., 2009).

In relation to the participants' mental health, there was a association between being tattooed and having a psychiatric diagnosis. Tattooing has been associated with psychopathology and deviance (D'Ambrosio, Martini, \& Casillo, 2014; Hawkes et al., 2004; Keith, King, \& Vidourek, 2013; Solano et al., 2014), especially in women (Mifflin, 1997). The prevalence of reported depressive disorder and/or anxiety disorder in our sample was also found in previous studies (Yen et al., 2012; Zrnoet al., 2015). Nonetheless, Frederick e Bradley (2000) found that tattooed individuals presented lower depression scores than their non-tattooed peers. Wethus concur with Stirn e Hinz (2008), who pointed that body modification practices can be connected to a large group of phenomena, from simple peer group imitation to a symptom of possibly severe psychopathological conditions, thus cautioning against associating psychological problems to tattooed individuals, for instance (Swami et al., 2016; Tate \& Shelton, 2008).

\section{Conclusions}

This analysis examined the motivational characteristics for getting tattooed and its relations with risk behaviors and other social practices in a sample of tattooed and non-tattooed Brazilian women, representing one of the first efforts to analyze quantitatively tattooing as an important social contemporary practice among the Brazilian population. The results presented here, albeit significant, offer just an incipient analysis, given the (small) sample size in comparison with the Brazilian population. However, it is noteworthy that our findings are consistent with many findings from prior researches presented above, and that this study represents an exploratory quantitative analysis of an important inquiry field that, in the Brazilian context, has been almost exclusively studied qualitatively. Future research would benefit from a mixed methodological approach (quantitative and qualitative), and could also focus on characteristics and social contexts of tattooed individuals.

Despite our merely preliminary results and the need to replicate them with larger samples, we agree with prior studies in that differences found between tattooed and non-tattooed individuals seem to have gradually diminished, suggesting that tattooed individuals tend to be more similar to their non-tattooed peers than dissimilar (Swami et al., 2016), which in turn is due to greater popularization and social acceptance of tattooing practices. Studies with tattooed men and comparative studies between the sexes also deserve more research efforts, generating findings that can favor a sustained scientific production on such field of inquiry.

\section{References}

Adams, J. (2009). Marked difference: tattooing and its association with deviance in the United States. Deviant Behavior, 30, 266-292. doi:10.1080/01639620802168817

Atik, D., \& Yildirim, C. (2014). Motivations behind acquiring tattoos and feelings of regret: Highlights from an Eastern Mediterranean context. Journal of Consumer Behaviour, 13, 212-223. doi:10.1002/ cb.1480.

Atkinson, M. (2002). Pretty in ink: Conformity, resistance, and negotiation in women's tattooing. Sex Roles, 47, 219-234. doi:10.1023/A:1021330609522

Armstrong, L. (1991). Career-oriented women with tattoos. Journal of Nursing Scholarship, 23, 215-220. doi:10.1111/j.1547-5069.1991.tb00674.x

Armstrong, M. L., Roberts, A., Koch, J., Saunders, J., Owen, D., \& Anderson, R. (2008). Motivation for Contemporary Tattoo Removal: a shift in identity. Archives of dermatology, 144(7), 879-884. doi:10.1001/archderm.144.7.879

Bicca, J. F., Duquia, R. P., Breunig, J. de A., Souza, P. R. do M. de, \& Almeida Jr, H. L. de. (2013). Tattoos on 18-year-old male adolescents - Characteristics and associated factors. Anais Brasileiros de Dermatologia, 88(6), 925-928. doi:10.1590/ abd1806-4841.20132192

Burgess, M., \& Clark, L. (2010). Do the "savageorigins" of tattoos cast a prejudicial shadow on contemporary tattooed individuals? Journal of Applied Social Psychology, 40(3), 746-764. doi:10.1111/j.1559-1816.2010.00596.x

Busaniche, J. N., Eymann, A. M., Mulli, V., Paz, M. C., \& Catsicaris, C. (2006). Asociación entre adolescentes 
tatuados y conductas de riesgo. Archivos Argentinos de Pediatría, 104(4), 309-315.

Byard, R. W., \& Charlwood, C. (2014). Commemorative tattoos as markers for anniversary reactions and suicide. Journal of Forensic and Legal Medicine, 24, 1517. doi:10.1016/j.jflm.2014.02.010

Carroll, L., \& Anderson, R. (2002). Body piercing, tattooing, self-esteem, and body investment in adolescent girls. Adolescence, 37(147), 627-637.

Chakraborty, S. (2013). 'A Skin of Ink': The Tattooist and the Body in Performance. Rupkatha Journal on Interdisciplinary Studies in Humanities, 5(2), 345-354.

Conti, M.A., Ferreira, M. E. C., Amaral, A.C. S., Hearst, N. C., Táki, A., \& Scagliusi, F.B. (2012). Equivalência Semântica da versão em português do "Body Change Inventory". Ciência \& Saúde Coletiva, 17(9), 2457-2469. doi:10.1590/ S1413-81232012000900026

Corso, D. L., \& Corso, M. (2014). Corpos ilustrados e enfeitados: tatuagens e marcas corporais. Revista Brasileira de Psicoterapia (Online), 16(1), 138-150.

Czupy, G., Pongó, G., Mihálffy, D., \& Susánszky, E. (2016). Health behavior of tattooed persons. Lege Artis Medicinae, 26(7-8), 351-358. doi:

Dadalte, A. C., Mariano, M. de C., Pedrão, L. J., Pedrão, G. B., \& Soares, E. J. P. (2013). Representations of tattoo and piercing use. SMAD. Revista eletrônica saúde mental álcool e drogas, 9(1), 41-47. doi:10.11606/ issn.1806-6976.v9i1p41-47

Degelman, D., \& Price, N.D. (2002). Tattoos and ratings of personal characteristics. Psychological Reports, 90, 507-514. doi:10.2466/pr0.2002.90.2.507

Deschesnes, M., Finès, P., \& Demers, S. (2006). Are tattooing and body piercing indicators of risk-taking behaviours among high school students? Journal of Adolescence, 29, 379-393. doi:10.1016/j. adolescence.2005.06.001

Dickson, L., Dukes, R., Smith, H., \& Strapko, N. (2014). Stigma of ink: Tattoo attitudes among college students. The Social Science Journal, 51(2), 268-276. doi:10.1016/j.soscij.2014.02.005

Drews, D. R., Allison, C. K., \& Probst, J. R. (2000). Behavioral and self-concept differences in tattooed and non tattooed college students. Psychological Reports, 86, 475-481. doi:10.2466/pr0.2000.86.2.475
D’Ambrosio, A., Martini, V., \& Casillo, N. (2014). Piercings and tattoos: Psychopathological aspects. Giornale di Neuropsichiatria dell'Età Evolutiva, 34(1), 1-10.

Forbes, G. B. (2001). College students with tattoos and piercings: Motives, family experiences, personality factors, and perception by others. Psychological Reports, 89, 774-786. doi:10.2466/pr0.2001.89.3.774

Frederick, C. M., \& Bradley, K. A. (2000). A different kind of normal? Psychological and motivational characteristics of young adult tattooers and body piercers. North American Journal of Psychology, 2, 379-389.

Gouveia, V. V, Medeiros, E. D. De, Mendes, L. A. de C., Vione, K. C., \& Athayde, R. A. A. (2010). Correlatos valorativos de atitudes frente à tatuagem. Psicologia e Sociedade, 22(3),476-485. doi:10.1590/ S0102-71822010000300008

Guéguen, N. (2012). Tattoos, piercings, and alcohol consumption. Alcoholism: clinical and experimental research, 36(7), 1253-1256. doi:10.1111/j.1530-0277.2011.01711.x

Hawkes, D., Senn, C. Y., \& Thorn, C. (2004). Factors that influence attitudes toward women with tattoos. Sex Roles, 50(9/10), 593-604. doi:10.1023/B:SERS.0000027564.83353.06

Heywood, W., Patrick, K., Smith, M. A., Simpson, J. M., Pitts, M. K., \& Richters Shelley, J. M. (2012). Who gets tattoos? Demographic and behavioral correlates of ever being tattooed in a representative sample of men and women. Annals of Epidemiology, 22(1), 51-56. doi:10.1016/j.annepidem.2011.10.005

Jennings, W. G., Fox, B. H., \& Farrington, D. P. (2014). Inked into crime? An examination of the causal relationship between tattoos and life-course of fending among males from the Cambridge study in delinquent development. Journal of Criminal Justice, 42(1), 77-84. doi:10.1016/j.jcrimjus.2013.12.006

King, K. A., \& Vidourek, R. A. (2013). Getting inked: Tattoo and risky behavioral involvement among university students. The Social Science Journal, 50, 540-546. doi:10.1016/j.soscij.2013.09.009

Kierstein, L., \& Kjelskau, K. C. (2015). Tattoo as art, the drivers behind the fascination and the decision to become tattooed. Current Problems in Dermatology, 48, 37-40. doi:10.1159/000369180 
Kluger, N. (2012). Le tatouage religieux. Annales de Dermatologie et de Vénéréologie, 139(11), 776-782. doi:10.1016/j.annder.2012.09.013

Kluger, N. (2015). Pregnancies in tattooed female tattooists: an observational study. European Journal of Obstetrics \& Gynecology and Reproductive Biology, 189, 112-114. doi:10.1016/j.ejogrb.2015.03.024

Koch, J. R., \& Roberts, A. E. (2012). The protestant ethic and the religious tattoo. The Social Science Journal, 49(2), 210-213. doi:10.1016/j.soscij.2011.10.001

Koch, J. R., Roberts, A. E., Armstrong, M. L., \& Owen, D. C. (2004). Correlations of religious belief and practice with college students' tattoo-related behavior. Psychology Reports, 94(2), 425-430. doi:10.2466/ pr0.94.2.425-430

Koch, J. R., Roberts, A. E., Armstrong, M. L., \& Owen, D. C. (2005). College students, tattoos, and sexual activity. Psychological Reports, 97, 887-890. doi:10.2466/pr0.97.3.887-890

Koch, J. R., Roberts, A. E., Armstrong, M. L., \& Owen, D. C. (2010). Body art, deviance, and American college students. The Social Science Journal, 47(1), 151-161. doi:10.1016/j.soscij.2009.10.001

Kosut, M. (2014). The artification of tattoo: Transformations within a cultural field. Cultural Sociology, 8(2), 142-158. doi:10.1177/1749975513494877

Koziel, S., \& Sitek, A. (2014). Self-assessment of attractiveness of persons with body decoration. Journal of Comparative Human Biology, 64, 317-325. doi:10.1016/j.jchb.2013.04.004

Laumann, A. E., \& Derick, A. (2006). Tattoos and body piercings in the United States: A national data set. Journal of The American Academy of Dermatology, 55(3), 413-421. doi:10.1016/j.jaad.2006.03.026

Le Breton, D. (2016). Adolescence and skin. Enfances et Psy, 68(4), 70-82. doi:10.3917/ep.068.0070

Macedo, S., \& Paravidini, J. L. L. (2015). O ato de tatuar-se: gozo e identificação o ato de tatuar-se. Tempo psicanalitico, 47(2), 138-155.

Macedo, S., Paravidini, J. L. P., \& Próchno, C. C. S C. (2014). Corpo e marca: tatuagem como forma de subjetivação. Revista Mal Estar e Subjetividade, 14(1), 152-161. doi:10.5020/23590777.14.1.152-161

Martin, B. A., \& Dula, C. S. (2010). More than skin deep: perceptions of, and stigma against, tattoos. College Student Journal, 44(1), 200-206.
Medeiros, E. D., Gouveia, V. V., Pimentel, C. E., Soares, A. K. S., \& Lima, T. J. S. (2010). Escala de atitudes frente à tatuagem (EAFT): elaboração e evidências de validade e precisão. Estudos de Psicologia, 27(2), 177-186. doi:10.1590/S0103-166X2010000200005

Mifflin, M. (1997). Bodies of subversion: A secret history of women and tattoo. New York: Juno Books.

Owen, D. C., Armstrong, M. L., Koch, J. R., \& Roberts, A. E. (2013). College students with body art: well-being or high-risk behavior? Journal of Psychosocial Nursing and Mental Health Services, 51(10), 20-28. doi:10.3928/02793695-20130731-03

Pajor, A. J., Broniarczyk-Dyła, G., \&Świtalska, J. (2015). Satisfaction with life, self-esteem and evaluation of mental health in people with tattoos or piercings. Psychiatria Polska, 49(3), 559-573. doi:10.12740/ $\mathrm{PP} / 27266$

Pinheiro, M., \& Carvalho, G. (2017). Singularidade e mito: o corpo como potência subversiva. Revista Latinoamericana de Psicopatologia Fundamental, 20(4), 728-748. doi:10.1590/1415-4714.2017v20n4p728.7

Rivardo, M. G., \& Keelan, C. M.(2010). Body modifications, sexual activity, and religious practices. Psychological Reports, 106(2), 467-74. doi:10.2466/ pr0.106.2.467-474

Roberts, A. E., Koch, J., Armstrong, M. L., \& Owen, D. C. (2006). Correlates of tattoos and reference groups. Psychological Reports, 99, 933-934. doi:10.2466/PR0.99.3.933-934

Rodriguez, L. da S., \& Carreteiro, T. C. O. C. (2014). Olhares sobre o corpo na atualidade: tatuagem, visibilidade e experiência tátil. Psicologia e Sociedade, 26(3), 746-755. doi:10.1590/S0102-71822014000300023

Seiter, J. S., \& Hatch, S. (2005). Effect of tattoos on perceptions of credibility and attractiveness. Psychological Reports, 96, 1113- 1120. doi:10.2466/ pr0.96.3c.1113-1120

Solano, P., Magagnoli, M., Pizzorno, E., Innamorati, M., Bruzzone, L., \& Amore, M. (2014). EPA-1070 - Suicide attempts and "body-art": is there any correlation? a preliminary study. European Psychiatry, 29(1), 1. doi:10.1016/S0924-9338(14)78351-8

Sosin, I. (2014). EPA-0786 - Tattoo as a subculture and new form of substantional addiction: The problem identification. European Psycbiatry, 29(1), 1. doi:10.1016/S0924-9338(14)78131-3

Psico-USF, Bragança Paulista, v. 25, n. 1, p. 51-62, jan./mar. 2020 
Stirn, A., \& Hinz, A. (2008). Tattoos, body piercings, and self-injury: Is there a connection? Investigations on a core group of participants practicing body modification. Psychotherapy Research, 18(3), 326- 333. doi:10.1080/10503300701506938

Stirn, A., Brähler, E., \& Hinz, A. (2006). Prevalence, sociodemography, mental health and gender differences of tattooing and body piercing. Psychotherapie, Psychosomatike, Medizinische Psychologie, 56(11), 445-449. doi:10.1055/s-2006-951817

Stirn, A., Hinz, A., \& Brähler, E. (2006). Prevalence of tattooing and body piercing in Germany and perception of health, mental disorders, and sensation seeking among tattooed and body-pierced individuals. Journal of Psychosomatic Research, 60(5), 531-534. doi:10.1016/j.jpsychores.2005.09.002

Stuppy, D.J., Armstrong, M.L., \& Casals-Ariet, C. (1998). Attitudes of health care providers and students toward tattooed people. Journal of Advanced Nursing, 27, 1165-1170. doi:10.1046/j.1365-2648.1998.00626.x

Swami, V. (2011). Marked for life? A prospective study of tattoos on appearance anxiety and dissatisfaction, perceptions of uniqueness, and self-esteem. Body Image, 8, 237- 244.

Swami, V. (2012). Written on the body? Individual differences between British adults who do and do not obtain a first tattoo. Scandinavian Journal of Psychology, 53, 407-412. doi:10.1016/j.bodyim.2011.04.005

Swami, V., \& Furnham, A. (2007). Unattractive, promiscuous, and heavy drinkers: Perceptions of women with tattoos. Body Image, 4, 343-352. doi:10.1016/j. bodyim.2007.06.005

Swami, V., Gaughan, H., Tran, U. S., Kuhlmann, T., Stieger, S., \& Voracek, M. (2015). Are tattooed adults really more aggressive and rebellious than those without tattoos? Body Image, 15, 149-152. doi:10.1016/j.bodyim.2015.09.001

Swami, V., Pietschnig, J.,Bertl, B., Nader, I. W., Stieger, S., \& Voracek, M. (2012). Personality differences between tattooed and non-tattooed individuals. Psychological Reports: Mental and Physical Health, 111(1), 97-106. doi:10.2466/09.07.21.PR0.111.4.97-106

Swami, V., Tran, U. S., Kuhlmann, T., Stieger, S., Gaughan, H., \& Voracek, M. (2016). More similar than different: Tattooed adults are only slightly more impulsive and willing to take risks than non-tattooed adults. Personality and Individual Differences, 88, 40-44. doi:10.1016/j.paid.2015.08.054

Tate, J. C., \& Shelton, B. L. (2008). Personality correlates of tattooing and body piercing in a college sample: The kids are alright. Personality and Individual Differences, 45, 281-285. doi:10.1016/j.paid.2008.04.011

Thakur, B. K., \& Verma, S. (2016). Tattoo practices in North-East India: A hospital-based cross-sectional study. Journal of Cutaneous and Aesthetic Surgery, 9(3), 172-176. doi:10.4103/0974-2077.191651

Tiggemann M., \& Golder, F. (2006). Tattooing: an expression of uniqueness in the appearance domain. Body Image, 3(4), 309-315. doi:10.1016/j. bodyim.2006.09.002

Tiggemann, M., \& Hopkins, L. (2011). Tattoos and piercings: bodily expressions of uniqueness. Body Image, 8, 245-250. doi:10.1016/j.bodyim.2011.03.007

Thompson, K. (2015). Comparing the psychosocial health of tattooed and non-tattooed women. Personality and Individual Differences, 74, 122-126. doi:10.1016/j.paid.2014.10.010

Wiseman, D. B. (2010). Perceptions of a tattooed college instructor. Psychological Reports, 106(3), 845-850. doi:10.2466/pr0.106.3.845-850

Wohlrab, S. Fink, B., Kappeler, P. M., \& Brewer, G. (2009). Perception of human body modification. Personality and Individual Differences, 46, 202-206. doi:10.1016/j.paid.2008.09.031

Wohlrab, S., Stahl, J., \& Kappeler, P. M. (2007). Modifying the body: Motivations for getting tattooed and pierced. Body Image, 4(1), 87-95. doi:10.1016/j. bodyim.2006.12.001

Yen, C-F., Hsiao, R. C., Yen, J-Y., Yeh, Y-C., \& Wang, P-W. (2012). Tattooing among high school students in southern Taiwan: The prevalence, correlates and associations with risk-taking behaviors and depression. Kaohsiung Journal of Medical Sciences, 28, 383-389. doi:10.1016/j.kjms.2011.10.008

Zrno, M., Frencl, M., Degmecic, D., \& Pozgain, I. (2015). Emotional profile and risk behaviours among tattooed and non-tattooed students. Medicinski Glasnik, 12(1), 93-98.

Recebido em: 05/03/2018

Reformulado em: 18/10/2018 e 19/12/2018

Aceito: 23/01/2019 
About the authors:

Adriano Schlösser - PhD in Psychology (UFSC). Post Doctorate in Human Movement Sciences (UDESC). Professor of Psychology at the Universidade do Oeste de Santca Catarina, Campus Videira. Associated researcher at the Laboratory of Social Psychology of Communication and Cognition (LACCOS/UFSC).

ORCID: https://orcid.org/0000-0002-1728-1414

E-mail: adriano.s@unoesc.edu.br

Andréia Isabel Giacomozzi - PhD in Psychology (UFSC). Adjunct Professor of the Department of Psychology at Universidade Federal de Santa Catarina. Linked to the PPGP-UFSC. Associated researcher at the Laboratory of Social Psychology of Communication and Cognition (LACCOS/UFSC).

ORCID: https://orcid.org/0000-0002-3172-5800

Brigido Vizeu Camargo - PhD in Social Psychology (École des Hautes Études en Sciences Sociales). Post Doctorate in Social Psychology (École des Hautes Études en Sciences Sociales). Full Professor of the Psychology Course at the Universidade Federal de Santa Catarina. Linked to the PPGP-USFC. Founding member of the Laboratory of Social Psychology of Communication and Cognition (LACCOS/UFSC).

ORCID: https://orcid.org/0000-0002-9529-4923

Emanuely Zelir Pereira da Silva - Masters in Psychology (UFSC). Associated researcher at the Laboratory of Social Psychology of Communication and Cognition (LACCOS/UFSC).

ORCID: https://orcid.org/0000-0001-5069-2090

Marlon Xavier - PhD in Social Psychology (Universitat Autònoma de Barcelona). Researcher linked to the Universitat Oberta de Catalunya (UOC) and collaborator at the Laboratory of Social Psychology of Communication and Cognition (LACCOS/UFSC).

ORCID: https://orcid.org/0000-0003-1003-5058

Contact:

Rua Antônio Marcon, 264, apt 401, Bairro Farroupilha

Videira-SC, Brasil 